Jurnal Health Sains: p-ISSN: 2723-4339 e-ISSN: 2548-1398

Vol. 2, No. 3, Maret 2021

\title{
HUBUNGAN PAJANAN PESTISIDA DENGAN EFEK NEUROBEHAVIORAL PADA PETANI CABAI MERAH DI KECAMATAN BERINGIN
}

Tina Meirindany, Sri Malem Indirawati, Irnawati Marsaulina

Universitas Sumatera Utara (USU) Medan Sumatera Utara, Indonesia

Email:meirindanytina@gmail.com, srimalem@usu.ac.id danirnamarsa@yahoo.com

\begin{tabular}{|c|c|}
\hline ARTIKEL INFO & ABSTRACT \\
\hline $\begin{array}{l}\text { Tanggal diterima: } 5 \text { Maret } 2021 \\
\text { Tanggal direvisi: } 15 \text { Maret } 2021 \\
\text { Tanggal disetujui: } 25 \text { Maret } 2021\end{array}$ & $\begin{array}{l}\text { One of the activities in improving the quality of } \\
\text { agricultural products is inseparable from the use of } \\
\text { pesticides. The use of pesticides in Indonesia is still }\end{array}$ \\
\hline $\begin{array}{l}\text { Keywords: } \\
\text { pesticide } \quad \text { exposure; } \\
\text { neurobehavioral effect; } \text { red chilli } \\
\text { grower }\end{array}$ & $\begin{array}{l}\text { dominated by chemical pesticides. Agricultural } \\
\text { businesses, especially red chili, still use pesticides from } \\
\text { the organophosphate group. Epideomyological studies } \\
\text { show that individuals who are exposed to acute and } \\
\text { chronic organophosphates will experience long-term } \\
\text { neurological disorders called neurobehavioral effects. } \\
\text { The purpose of this study was to analyze pesticide } \\
\text { exposure with neurobehavioral effects on red chilli } \\
\text { farmers in Beringin District. This type of research is } \\
\text { analytic observational research with cross sectional } \\
\text { design. The research population is all red chili farmers } \\
\text { who are members of the Juli Tani group, Sidodadi } \\
\text { Ramunia village. Samples were } 46 \text { red chili farmers. Data } \\
\text { collection using the German version of the Q18 } \\
\text { questionnaire which was followed by a neurobehavioral } \\
\text { performance test using digit symbol instruments, digist } \\
\text { span, pursuit aiming and trail making. Results as many as } \\
\text { 60.9\% of farmers experienced abnormal neurobehavioral } \\
\text { effects and } 39.1 \% \text { of farmers experienced normal } \\
\text { neurobehavioral effects, from the results of the chi square } \\
\text { test showed there was a relationship between age (p = } \\
\text { 0.003), length of work (p = 0,000), and type of pesticides } \\
\text { ( } p=0.013 \text { ) with neurobehavioral effects on red chilli } \\
\text { farmers in Beringin District. Conclusion age, the length } \\
\text { of work, and types of pesticides can cause abnormal } \\
\text { neurobehavioral effects on red chilli farmers in Beringin } \\
\text { District. }\end{array}$ \\
\hline
\end{tabular}

\section{ABSTRAK}

Salah satu kegiatan dalam meningkatkan kualitas hasil pertanian tidak terlepas dari penggunaan pestisida. Penggunaan pestisida di Indonesia masih didominasi pestisida berbahan kimia. Usaha pertanian khususnya cabai merah masih menggunakan pestisida dari golongan organofosfat. Berbagai studi epideomiologi menunjukkan bahwa individu yang terpapar organofosfat secara akut dan kronik akan mengalami gangguan neurologis jangka panjang yang disebut efek neurobehavioral. Tujuan 
Kata Kunci:

pajanan pestisida; neurobehavioral; petani merah penelitian ini untuk menganalisis pajanan pestisida dengan efek neurobehavioral pada petani cabai merah di Kecamatan Beringin. Jenis penelitian ini adalah penelitian observasional analitik dengan desain cross sectional. Populasi penelitan adalah seluruh petani cabai merah yang tergabung dalam kelompok Juli Tani desa Sidodadi Ramunia. Sampel adalah 46 petani cabai merah. Pengumpulan data menggunakan kuisioner Q18 Versi Jerman yang dilajutkan dengan uji performa neurobehavioral menggunakan instrument digit symbol, digist span, pursuit aiming dan trail making. Hasil sebanyak $60,9 \%$ petani mengalami efek neurobehavioral tidak normal dan $39,1 \%$ petani mengalami efek neurobehavioral normal, berdasarkan analisis menunjukkan ada hubungan antara usia $(\mathrm{p}=0,003)$, masa kerja $(p=0,000)$, dan jenis pestisida $(p=0,013)$ dengan efek neurobehavioral pada petani cabai merah di Kecamatan Beringin. Kesimpulan usia, masa kerja petani, efek dan jenis pestisida dapat menyebabkan efek cabai neurobehavioral tidak normal pada petani cabai merah di Kecamatan Beringin.
Coresponden Author:

Email: meirindanytina@gmail.com Artikel dengan akses terbuka dibawah lisensi

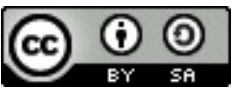

\section{Pendahuluan}

Indonesia merupakan salah satu negara agrikultural yang cukup berkembang dalam sektor pertanian. Berdasarkan data hasil Survei Pertanian Antar Sensus tahun 2018 melaporkan bahwa jumlah penduduk yang bekerja disektor pertanian di seluruh provinsi berjumlah 33.487.806 jiwa. Peningkatan hasil pertanian tidak terlepas dari penggunaan pestisida. Pestisida berbahan kimia masih dominan digunakan para petani. Menurut penelitian (Bouwknegt et al., 2018) menyatakan dunia telah menggunakan pestisida sekitar 2,4 megaton dan Amerika Sertikat telah menggunakan pestisida sekitar 0,5 megaton. Berdasarkan data Kementerian Pertanian, Indonesia menduduki urutan pertama penggunaan pestisida tertinggi di Asia Tenggara.

Penggunaan pestisida kimia secara masif telah memberikan dampak negatif baik terhadap manusia. Berdasarkan informasi (Organization, 2013) bahwa penyebab kematian 12,6 juta orang pertahun salah satunya disebabkan oleh pestisida. Kasus keracunan pestisida juga banyak terjadi di Indonesia. Berdasarkan data Sentra Informasi Keracunan Nasional melaporkan tahun 2014 telah terjadi 710 kasus keracunan pestisida dan meningkat menjadi 771 kasus di tahun 2016.

Usaha pertanian cabai merah masih menggunakan insektisida dari golongan organofosfat. Berbagai studi epideomiologi menunjukkan bahwa individu yang terpapar organofosfat secara akut dan kronik akan mengalami gangguan neurologis jangka panjang sehingga memengaruhi fungsi saraf yang menimbulkan efek neurobehavioral. United State Environmental Protection Agency (US EPA) melaporkan bahwa efek neurobehaioval merupakan salah satu dari 10 
gangguan kesehatan di tempat kerja. gangguan sistem saraf ini mudah di identifikasi melalui gejala-gejala yang dirasakan oleh seseorang yang terpapar oleh pestisida seperti pusing, kelelahan yang berlebihan, susah tidur, dan sulit berkonsentrasi. Cara mengetahui adanya efek neurobehavioral akibat pajanan pestisida dapat identifikasi melalui kuesioner Q18 versi Jerman, keluhan ini mengacu pada atensi, memori, konsentrasi serta suasana hati, selanjutnya dibuktikan melalui uji performa neurobehavioral yang disebut Neurobehavioral Core Test Battery. UJi performa ini dikenalkan oleh Helena Hanninen dan ditetapkan WHO sejak tahun 1986 sebagai standarisasi untuk mendeteksi gangguan sistem saraf. Gejala distribusi neurobehavioral akibat paparan pestisida dapat diasosiasikan dengan keluhan yang dievaluasi melalui kuesioner Q18 versi Jerman. Kuesioner ini bertujuan menggambarkan gejala distribusi neurobehavioral akibat pajanan zat neurotoksikan.

Berdasarkan survey pendahuluan pada petani cabai merah di desa Sidodadi Ramunia, usaha pertanian cabai merah sudah berlangsung selama 37 tahun. Beberapa petani cabai merah juga mengalami gejala neurobehavioral yang didukung berdasarkan kuesioner Q18 Versi Jerman seperti merasa kesulitan mengerti isi surat kabar atau buku, sering melupakan kejadian yang baru saja terjadi, sulit berkonsentrasi, sering merasa lelah berlebihan dan sakit kepala sekali yang dialami dalam seminggu atau lebih. Berdasarkan fakta yang telah diuraikan di atas, penelitian ini bertujuan untuk menganalisis hubungan pajanan pestisida dengan efek neurobehavioral pada petani cabai merah di Kecamatan Beringin.

Tujuan penelitian ini adalah untuk mengetahui hubungan pajanan pestisida dengan efek neurobehavioral pada petani cabai merah di kecamatan beringin.

\section{Metode Penelitian}

Penelitian ini merupakan penelitian observasional analitik dengan rancangan cross sectional. Penelitian ini dilakukan pada bulan Maret sampai April 2020. Populasi seluruh petani cabai merah yang tergabung dalam kelompok Juli Tani Desa Sidodadi Ramunia Kecamatan Beringin sebanyak 105 orang. Jumlah sampel dalam penelitian ini ditentukan berdasarkan rumus Lemshow (1997)

$\mathrm{n} \geq \llbracket(\mathrm{Za} \sqrt{\mathrm{P} 0}(1-\mathrm{P} 0)+\mathrm{Z} \beta \sqrt{\mathrm{Pa}}(1-\mathrm{Pa}$

)$) \rrbracket \wedge 2 /((\mathrm{Pa}-\mathrm{P} 0) 2)$

$\mathrm{n}$ : Besar sampel

$1-a / 2$ : Nilai deviasi normal pada tingkat kemaknaan $\mathrm{a}=0,05$ yaitu 1,96

$1-\beta \quad$ : Kekuatan uji bila $\beta=20 \%$, maka $\mathrm{Z} \beta=0,842$

$P 0 \quad$ : Petani yang tidak mengalami gejala neurotoksik $(56) /(90)=0,62$

$P a: \quad$ Petani yang mengalami gejala neurotoksik34/(90) $=0,38$

$P a-P 0$ : Selisih proporsi yang bermakna ditetapkan sebesar $20 \%$

$\mathrm{n} \geq 46$, Jumlah sampel dalam penelitian ini 46 orang.

Pengumpulan data menggunakan kuesioner Q18 Versi Jerman dan dilanjutkan dengan uji neurobehavioral core tes battery dengan menggunakan instrumen digit symbol, digit span, pursuit aiming dan trail making oleh tim psikologi.

Data dianalisis secara deskriptif pada masing-masing variabel yang diteliti. Analisis inferensial dilakukan dengan uji Chi-Square untuk mengetahui hubungan kemaknaan antara variabel bebas dan terikat.

\section{Hasil dan Pembahasan}

\section{A. Hasil Penelitian}

1. Deskripsi Variabel Penelitian.

Petani yang paling banyak merasakan gejala neurobehavioral pada pertanyaan no 1 yaitu sering merasa lupa pada hal yang baru saja terjadi dan 
petani yang merasakan keluhan paling sedikit yaitu pada pertanyaan no 10 yaitu sering merasa sakit seperti tertekan di dada dan pertanyaan no 17 dimana merasakan tangan sering bergetar.

Tabel 1

Distribusi Frekuensi Gejala Neurobeha ioral

\begin{tabular}{lll}
\hline Variabel & Mean \pm SD & $\begin{array}{l}\text { Min- } \\
\text { Maks }\end{array}$ \\
Usia & $41,73 \pm$ & $27-$ \\
& 6,62 & 53 \\
\hline Masa Kerja Gejala & $17,10 \pm 7,61$ & $5-35$ \\
\hline Distribusi & $5,10 \pm 2,26$ & $1-13$ \\
Neurobehavioral & &
\end{tabular}

Berdasarkan hasil penelitian tabel 2 dapat diketahui bahwa nilai mean dari variabel usia adalah 41,73. Hal ini menunjukkan dari 46 petani memiliki rata-rata usia 41,73 tahun dengan usia responden minimum 27 tahun dan maksimum 53 tahun. Nilai mean variabel masa kerja adalah 17,10 dimana menunjukkan bahwa rata-rata masa kerja petani selama 17,10 tahun dengan masa kerja minimum 5 tahun dan maksimum 35 tahun. Selanjutnya nilai mean gejala distribusi neurobehavioral adalah 5,10 yang menunjukkan bahwa rata-rata responden memiliki 5,1 distribusi gejala neurobehavioral dengan distribusi gejala neurobehavioral minimum adalah 1 gejala dan distribusi gejala neurobehavioral.
Tabel 2

Nilai Mean dan SD Usia, Masa Kerja dan Distribusi Gejala Neurobehavioral

\begin{tabular}{|c|c|c|c|c|c|}
\hline No & Pertanyaan & & Ya & & dak \\
\hline 1 & $\begin{array}{l}\text { Apakah Anda } \\
\text { merasa pelupa pada } \\
\text { hal yang baru saja } \\
\text { terjadi? }\end{array}$ & 45 & 97,8 & 1 & 2,2 \\
\hline 2 & $\begin{array}{l}\text { Apakah ada } \\
\text { keluarga anda yang } \\
\text { mengatakan anda } \\
\text { sering lupa pada hal } \\
\text { yang baru saja } \\
\text { terjadi? }\end{array}$ & 22 & 47,8 & 24 & 52,2 \\
\hline 3 & $\begin{array}{l}\text { Apakah anda sering } \\
\text { harus mencatat } \\
\text { tentang hal yang } \\
\text { tidak boleh anda } \\
\text { lupakan? }\end{array}$ & 8 & 17,4 & 38 & 82,6 \\
\hline 4 & $\begin{array}{l}\text { Apakah anda secara } \\
\text { umum menemukan } \\
\text { kesulitan mengerti } \\
\text { isi surat kabar dan } \\
\text { buku? }\end{array}$ & 10 & 21,7 & 36 & 78,3 \\
\hline 5 & $\begin{array}{l}\text { Apakah anda sulit } \\
\text { berkonsentrasi? }\end{array}$ & 39 & 84,8 & 7 & 15,2 \\
\hline 6 & $\begin{array}{l}\text { Apakah anda } \\
\text { merasa sering } \\
\text { mudah emosi tanpa } \\
\text { sebab yang jelas? }\end{array}$ & 20 & 43,5 & 26 & 56,5 \\
\hline 7 & $\begin{array}{l}\text { Apakah anda sering } \\
\text { merasa sedih atau } \\
\text { depresi tanpa sebab } \\
\text { yang jelas? }\end{array}$ & 7 & 15,2 & 39 & 84,8 \\
\hline 8 & $\begin{array}{l}\text { Apakah anda sering } \\
\text { merasa lelah diluar } \\
\text { kebiasaan? }\end{array}$ & 15 & 32,6 & 31 & 67,4 \\
\hline 9 & $\begin{array}{lr}\text { Pernahkah } & \text { anda } \\
\text { merasakan jantung } \\
\text { berdebar tanpa } \\
\text { adanya } \\
\text { tekanan/melakukan } \\
\text { apapun? }\end{array}$ & 7 & 15,2 & 39 & 84,8 \\
\hline 10 & $\begin{array}{l}\text { Apakah anda sering } \\
\text { merasa sakit seperti } \\
\text { ditekan didada? }\end{array}$ & 1 & 2,2 & 45 & 97,8 \\
\hline 11 & $\begin{array}{lr}\text { Apakah } & \text { anda } \\
\text { berkeringat } & \text { tanpa } \\
\end{array}$ & 7 & 15,2 & 39 & 84,8 \\
\hline
\end{tabular}




\begin{tabular}{|c|c|c|c|c|c|}
\hline & sebab yang jelas? & & & & \\
\hline 12 & $\begin{array}{l}\text { Apakah anda sering } \\
\text { sakit kepala sekali } \\
\text { dalam seminggu } \\
\text { atau lebih? }\end{array}$ & 17 & 37,0 & 29 & 63,0 \\
\hline 13 & $\begin{array}{lr}\text { Apakah keinginan } \\
\text { seksualitas anda } \\
\text { berkurang } \\
\text { biasanya? }\end{array}$ & 3 & 6,5 & 43 & 93,5 \\
\hline 14 & $\begin{array}{l}\text { Apakah anda sering } \\
\text { merasa tidak sehat? }\end{array}$ & 5 & 10,9 & 41 & 89,1 \\
\hline 15 & $\begin{array}{l}\text { Apakah ada rasa } \\
\text { kebal/baal pada } \\
\text { tangan/kaki anda? }\end{array}$ & 18 & 39,1 & 28 & 60,9 \\
\hline 16 & $\begin{array}{l}\text { Apakah ada rasa } \\
\text { atau lemah pada } \\
\text { lengan/tungkai kaki } \\
\text { anda? }\end{array}$ & 10 & 21,7 & 36 & 78,3 \\
\hline 17 & $\begin{array}{l}\text { Apakah tangan } \\
\text { anda bergetar? }\end{array}$ & 1 & 2,2 & 45 & 97,8 \\
\hline 18 & $\begin{array}{l}\text { Apakah anda } \\
\text { terbiasa dengan } \\
\text { minuman } \\
\text { beralkohol? }\end{array}$ & 2 & 4,3 & 44 & 95,7 \\
\hline
\end{tabular}

Berdasarkan tabel 2, pada variabel jenis kelamin diketahui bahwa jumlah responden yang berjenis kelamin laki-laki sebanyak 33 orang $(71,7 \%)$ dan responden yang berjenis kelamin perempuan sebanyak 13 orang $(28,3 \%)$. Pada variabel usia diketahui bahwa usia petani diatas atau sama dengan 40 tahun berjumlah 30 orang $(65,2 \%)$ dan usia petani dibawah 40 tahun sebanyak 16 orang $(34,8 \%)$. Pada variabel jenis pestisida diketahui bahwa responden yang menggunakan jenis pestisida organofosfat sebanyak 15 orang $(32,6 \%) \quad 31$ orang $(67,4 \%)$ menggunakan pestisida non organofosfat. Pada variabel lama penyemprotan diketahui bahwa petani yang melakukan penyemprotan lebih dari 2 kali dalam satu minggu dan lama penyemprotan lebih dari 2 jam perhari sebanyak 11 orang $(23,9 \%)$ dan petani yang melakukan penyemprotan kurang atau sama dengan 2 kali dalam satu minggu dan lama penyemprotan kurang atau sama dengan 2 jam perhari sebanyak 35 orang $(76,1 \%)$.

Pada variabel masa kerja diketahui bahwa petani yang bekerja lebih dari atau sama dengan 10 tahun sebanyak 33 orang $(71,7 \%)$ dan 13 orang $(28,3 \%)$ menyatakan kurang dari 10 tahun. Pada variabel penggunaan APD diketahui bahwa responden dengan penggunaan APD tidak lengkap 36 orang $(78,3 \%)$ dan 10 orang $(21,7 \%)$ dengan penggunaan APD lengkap. Pada variabel dependen yaitu efek neurobehavioral diketahui bahwa responden dengan efek neurobehavioral tidak normal sebanyak 28 orang $(60,9 \%)$ dan responden dengan efek neurobehavioral normal sebanyak 18 orang $(39,1 \%)$.

Tabel 3

Distribusi Frekuensi Karakteristik Individu, Jenis Pestisida, Frekuensi Penyemprotan, Masa Kerja, Penggunaan APD, dan Efek Neurobehavioral pada Petani Cabai Merah di Kecamatan Beringin

\begin{tabular}{|c|c|c|}
\hline Variabel & $\begin{array}{c}n \\
=46\end{array}$ & $\begin{array}{c}\text { Persen } \\
(\%)\end{array}$ \\
\hline \multicolumn{3}{|l|}{ Jenis Kelamin } \\
\hline Laki-laki & 33 & 71.7 \\
\hline Perempuan & 13 & 28.3 \\
\hline \multicolumn{3}{|l|}{ Usia } \\
\hline$\geq 40$ Tahun & 30 & 65.2 \\
\hline$<40$ Tahun & 16 & 34.8 \\
\hline \multicolumn{3}{|l|}{ Jenis Pestisida } \\
\hline Organofosfat & 15 & 32.6 \\
\hline Non & 31 & 67.4 \\
\hline Organofosfat & & \\
\hline \multicolumn{3}{|c|}{ Lama Penyemprotan } \\
\hline$>2 \mathrm{jam} / \mathrm{hari}$ & 11 & 23.9 \\
\hline$\leq 2$ jam/hari & 35 & 76.1 \\
\hline \multicolumn{3}{|l|}{ Masa Kerja } \\
\hline$\geq 10$ Tahun & 33 & 71.7 \\
\hline$<10$ Tahun & 13 & 28.3 \\
\hline \multicolumn{3}{|l|}{ Penggunaan APD } \\
\hline Tidak Lengkap & 36 & 78.3 \\
\hline
\end{tabular}




\begin{tabular}{lcc}
\hline \multicolumn{1}{c}{ Lengkap } & 10 & 21.7 \\
\cline { 1 - 1 } Efek Neurobehavioral & \\
\hline $\begin{array}{l}\text { Efek } \\
\text { neurobehavioral } \\
\text { tidak normal }\end{array}$ & 28 & 60.9 \\
\cline { 1 - 1 } $\begin{array}{l}\text { Efek } \\
\text { neurobehavioral } \\
\text { normal }\end{array}$ & & 39.1 \\
\hline
\end{tabular}

Tabel 4

Tabulasi Silang Hubungan Karakteristik Individu, Jenis Pestisida, Lama

Penyemprotan, Masa Kerja, Penggunaan APD terhadap Efek Neurobehavioral pada

Petani Cabai Merah di Kecamatan Beringin Kabupaten Deli Serdang

\begin{tabular}{|c|c|c|c|c|c|c|c|}
\hline \multirow{3}{*}{ Variabel } & \multicolumn{6}{|c|}{ Efek Neurobehavioral } & \multirow{3}{*}{$\begin{array}{c}\text { p. } \\
\text { value }\end{array}$} \\
\hline & \multicolumn{2}{|c|}{$\begin{array}{l}\text { Tidak } \\
\text { Normal } \\
\end{array}$} & \multicolumn{2}{|c|}{ Normal } & \multicolumn{2}{|c|}{ Total } & \\
\hline & $\bar{n}$ & $\%$ & n & $\%$ & $\mathbf{n}$ & $\%$ & \\
\hline \multicolumn{7}{|l|}{ Jenis Kelamin } & \multirow{3}{*}{0,466} \\
\hline Laki-laki & 19 & 57,6 & 14 & 42,4 & 33 & 100,0 & \\
\hline Perempuan & 9 & 69,2 & 4 & 30,8 & 13 & 100,0 & \\
\hline \multicolumn{7}{|l|}{ Usia } & \multirow{3}{*}{0,003} \\
\hline$\geq 40$ Tahun & 23 & 76,7 & 7 & 23,3 & 30 & 100,0 & \\
\hline$<40$ Tahun & 5 & 31,3 & 11 & 68,7 & 16 & 100,0 & \\
\hline \multicolumn{7}{|l|}{ Jenis Pestisida } & \multirow{3}{*}{0,013} \\
\hline Organofosfat & 13 & 86,7 & 2 & 13,3 & 15 & 100,0 & \\
\hline Non Organofosfat & 15 & 48,4 & 16 & 51,6 & 31 & 100,0 & \\
\hline \multicolumn{7}{|c|}{ Lama Penyemprotan } & \multirow[b]{3}{*}{1} \\
\hline$>2 \mathrm{jam} / \mathrm{hari}$ & 7 & 63,6 & 4 & 36,4 & 11 & 100,0 & \\
\hline$\leq 2 \mathrm{jam} / \mathrm{hari}$ & 21 & 60,0 & 14 & 40,0 & 35 & 100,0 & \\
\hline \multicolumn{7}{|l|}{ Masa Kerja } & \multirow[b]{3}{*}{0,000} \\
\hline$\geq 10$ Tahun & 26 & 78,8 & 7 & 21,2 & 33 & 100,0 & \\
\hline$<10$ Tahun & 2 & 15,4 & 11 & 84,6 & 13 & 100,0 & \\
\hline \multicolumn{7}{|l|}{ Penggunaan APD } & \multirow{3}{*}{$\underline{0,480}$} \\
\hline Tidak Lengkap & 23 & 63,9 & 13 & $\underline{36,1}$ & 36 & 100,0 & \\
\hline Lengkap & 5 & $\overline{50,0}$ & 5 & $\overline{50,0}$ & 10 & $\overline{100,0}$ & \\
\hline
\end{tabular}

\section{B. Pembahasan}

1. Hubungan Jenis Kelamin dengan Efek Neurobehavioral pada Petani Cabai Merah di Kecamatan Beringin

Berdasarkan tabel 3 dapat diketahui bahwa hasil analisis hubungan jenis kelamin dengan efek neurobehavioral didapatkan nilai $\mathrm{p}=0,466$ yang menyatakan bahwa tidak hubungan jenis kelamin terhadap efek neurobehavioral.

Hasil penelitian ini sejalan dengan penelitian oleh (Zhang \&
Wallace, 2015) pada pekerja pertanian di Jiangsu dimana tidak ada hubungan antara jenis kelamin dengan efek neurobehavioral $\quad(p=0,952)$ pada pekerja pertanian di Jiangsu China.

Pada penelitian ini 19 orang petani laki-laki mengalami efek neurobehavioral dan 9 orang petani perempuan juga mengalami efek neurobehavioral. Efek neurobehavioral serta gangguan saraf lainnya dapat dialami oleh setiap individu baik pada laki-laki maupun perempuan. Menurut (Meryana et al., 2016) pada prinsipnya laki-laki dan perempuan bisa terkena penyakit saraf yang sama. Hanya saja ada beberapa hal yang membedakan pengaruhnya terhadap gangguan saraf tergantung berdasarkan respon tubuh yang diterima oleh seseorang. Penyakit saraf pada perempuan pada umumnya banyaknya dipicu oleh faktor hormonal.

2. Hubungan Usia dengan Efek Neurobehavioral pada Petani Cabai Merah di Kecamatan Beringin

Hasil analisis hubungan usia dengan efek neurobehavioral didapatkan nilai $\mathrm{p}=0,003$ sehingga ada hubungan usia dengan efek neurobehavioral pada petani cabai merah di Kecamatan Beringin. Hasil penelitian ini sejalan dengan penelitian (Kim et al., 2019) bahwa terdapat hubungan paparan pestisida kronis pada kelompok usia tertentu $(60-69$ tahun) di wilayah pedesaan Korea Selatan $(p=0,003)$ dengan gangguan saraf pusat dalam fungsi mengingat. Hasil penelitian ini juga sama dengan hasil penelitian (Zhang \& Wallace, 2015) dimana ada hubungan usia dengan efek neurobehavioral pada petani di Jiangsu China $(p=0,04)$. 
Menurut (Kandel \& Squire, 2000) menjelaskan bahwa sistem saraf akan melalui tahap perubahan ke arah reduksi yang terjadi pada rentang usia 40 tahun dimana otak dan sum-sum tulang belakang akan kehilangan sel saraf. Sel-sel saraf juga mulai menyampaikan pesan lebih lambat dari pada sebelumnya.

Selain itu, berbagai penelitian melaporkan bahwa hipocampus (bagian dari sistem limbik) yang berperan pada kegiatan mengingat akan dipengaruhi oleh peningkatan kadar hormon steroid adrenalin kronis yang pada umumnya ditemukan pada usia dewasa sehingga mengakibatkan ukuran hypokampus akan semakin mengecil (Svennigsen \& Dahlin, 2013).

3. Hubungan Jenis Pestisida dengan Efek Neurobehavioral pada Petani Cabai Merah di Kecamatan Beringin

Berdasarkan hasil analisis hubungan jenis pestisida terhadap efek neurobehavioral pada petani cabai merah di Kecamatan Beringin Kabupaten Deli Serdang menunjukkan bahwa ada hubungan antara variabel jenis pestisida dengan efek neurobehavioral $(\mathrm{p}=0,013)$.

Hasil penelitian ini menunjukkan bahwa efek neurobehavioral dapat dialami baik dari petani yang menggunakan pestisida organofosfat dan petani yang menggunakan pestisida non organofosfat karena bahan aktif yang terkandung dalam pestisida berbahaya bagi kesehatan tubuh serta diperparah dengan berbagai faktor internal dan faktor eksternal pada petani sebagai penyebab terjadinya efek neurobehavioral.

Hasil penelitian ini sejalan dengan hasil penelitian (Gusti \& Desnizar, 2017) yang menunjukkan bahwa ada hubungan jenis pestisida terhadap gejala neurotoksik $(\mathrm{p}=0,002)$ dimana responden yang mengalami gejala neurotoksik dengan penggunaan pestisida golongan organofosfat dimana $\quad 40$ orang $(74,1 \%)$ menggunakan pestisida jenis organofosfat dan 7 orang $(33,3 \%)$ menggunakan pestisida dari jenis non organofosfat.

Defisit performa neurobehavioral akibat paparan organofosfat disebabkan sifat organofosfat yang memodulasi sistem saraf. Organofosfat menghambat kerja enzim karboksilat esterase, asetilkolinesterase,pseudokolinesterase secara irreversibel sehingga terjadi akumulasi asetilkolin pada sinapsis muskarinik, nikotinik, dan sistem saraf pusat. Asetilkolinesterase yang tidak terbentuk menyebabkan kelebihan asetilkolin bebas yang berkepanjangan dalam sistem saraf otonom, dan sistem saraf pusat sehingga berkontribusi dalam keterlambatan perkembangan neurobehavior. (Androutsopoulos, 2013 dalam Wiadi \& Muliarta, 2017).

Berdasarkan hasil penelitian diketahui bahwa 15 responden yang menggunakan pestisida dari jenis non organofosfat juga mengalami efek neurobehavioral. Petani menggunakan insektisida golongan neonikotinoid seperti winder (imidakloprid) dan ares (nitenpiram). Cemaran jenis pestisida ini berbahaya karena menyebabkan pusing, sakit didada, mual dan muntah. Gangguan kesehatan ini timbul akibat adanya zat neonik jenis imidacloprid serta neonik lainnya yang mekanismenya hampir sama dengan jenis organofosfat. Gejala lain yang ditimbulkan paparan neonikotionid yaitu gangguan $j$ (Watts, 2011). 
4. Hubungan Lama Penyemprotan dengan Efek Neurobehavioral pada Petani Cabai Merah di Kecamatan Beringin

Hasil analisis hubungan variabel lama penyemprotan dengan efek neurobehavioral didapatkan nilai $\mathrm{p}=1$ yang menyatakan bahwa tidak ada hubungan lama penyemprotan dengan efek neurobehavioral pada petani cabai merah di Kecamatan Beringin. Sebagian petani melakukan penyemprotan hanya pada waktu tertentu seperti pada pagi hari atau pada sore hari dan penyemprotan pestisida juga tidak lama karena lahan pertanian tidak terlalu luas. Mayoritas petani melakukan pengerjaan pada pagi hari selama 1 jam kemudian dilanjutkan sore hari selama 1 jam.

Hasil penelitian ini tidak sejalan dengan penelitian Samosir., et.al (2017) bahwa ada pengaruh lama penyemprotan dengan gangguan sistem saraf pada keseimbangan tubuh petani holtikultura di Kecamatan Ngablak Magelang $(\mathrm{p}=0,015)$, variabel lama penyemprotan berisiko 6,593 kali mengalami gangguan sistem saraf pada keseimbangan tubuh. Hasil penelitian ini juga tidak sejalan dengan hasil penelitian Zulmi (2016) pada petani di Desa Kembang Kuning Kecamatan Cepego dimana lama penyemprotan pestisida berhubungan dengan penurunan kadar cholinesterase dalam darah. $(\mathrm{p}=0,000)$.

Lama kerja petani yang diimbangi dengan istirahat yang cukup dapat mengembalikan aktivitas kholinesterase dalam darah. Pengerjaan penyemprotan pestisida yang dilakukan petani yaitu memulai aktivitas di pagi hari, beristirahat di siang hari dan melanjutkan kembali di sore hari (Lucki., et.al. 2018).
5. Hubungan Masa Kerja dengan Efek Neurobehavioral pada Petani Cabai Merah di Kecamatan Beringin

Berdasarkan hasil analisis hubungan variabel masa kerja dengan efek neurobehavioral didapatkan nilai $\mathrm{p}=0,000$ yang menyatakan bahwa ada hubungan masa kerja dengan efek neurobehavioral pada petani cabai merah di Kecamatan Beringin.

Hasil penelitian ini tidak sejalan dengan penelitian (Rahmah et al., 2012) bahwa tidak terdapat hubungan masa kerja dengan gejala neurotoksik akibat pajanan xylen pada pekerja pembuatan cat $(\mathrm{p}=1)$. Hasil penelitian ini sejalan dengan penelitian (Samosir et al., 2017) bahwa ada hubungan masa kerja seseorang dengan gangguan sistem saraf pada keseimbangan tubuh petani holtikultura di Kecamatan Ngablak dengan $\mathrm{p}=0,036$.

Semakin lama masa kerja yang dialami oleh petani maka semakin besar pula residu zat toksik yang masuk kedalam tubuh. Zat toksik tersebut diabsorbsi, diangkut melalui sawar darah otak menuju otak sehingga terakumulasi dalam jaringan otak yang mengakibatkan rusaknya sel -sel saraf, mengakibatkan terjadi abnormalitas pada fungsi saraf seperti perlambatan daya olah pikir, memori dan konsentrasi (Kandel \& Squire, 2000).

6. Hubungan Penggunaan APD dengan Efek Neurobehavioral pada Petani Cabai Merah di Kecamatan Beringin

Pada hasil analisis hubungan penggunaan APD dengan efek neurobehavioral nilai $\mathrm{p}=0,480$, menunjukkan bahwa tidak ada hubungan penggunaan APD dengan efek neurobehavioral pada petani cabai merah di Kecamatan Beringin. 
Berdasarkan hasil wawancara, petani menyatakan bahwa mereka merasa kurang nyaman dengan pemakaian APD lengkap dengan alasan kurang leluasa dalam beraktivitas, bahkan mayoritas petani tidak pernah menggunakan sarung tangan dan kacamatan pengaman ketika melakukan penyemprotan. Selain itu, mereka juga jarang membersihkan alat penyemprotan setelah digunakan bahkan ada juga yang mengaku tidak pernah membersihkan peralatan tersebut.

Hasil penelitian ini sejalan dengan penelitian (Rahmah et al., 2012) yang menyatakan bahwa ada hubungan penggunaan APD dengan gejala distribusi neurobehavioral akibat pajanan xylen pada pekerja pembuatan cat $(p=0,530)$. Hasil penelitian ini tidak sejalan dengan penelitian (Samosir et al., 2017) bahwa ada hubungan penggunaan APD dengan gangguan sistem saraf berupa keseimbangan tubuh $(\mathrm{p}=0,035) \quad$ pada petani holtikultura di Kecamatan Ngablak Magelang.

Berdasarkan (Rahmadani, 2020), alat pelindung diri merupakan suatu alat yang mempunyai kemampuan untuk melindungi seseorang yang fungsinya mengisolasi sebagian atau seluruh tubuh dari potensibahaya pada suatu tempat kerja

\section{Kesimpulan}

Penelitian ini menyimpulkan bahwa Sebanyak $60,9 \%$ petani mengalami efek neurobehvaioral tidak normal dan 30,1\% petani yang mengalami efek neurobehavioral normal, ada hubungan usia $(\mathrm{p}=0,003)$, masa kerja $(p=0,000)$, jenis pestisida $(p=0,013)$ dengan efek neurobehavioral pada petani cabai merah di Kecamatan Beringin, tidak ada hubungan jenis kelamin $(p=0,466)$, lama penyemprotan $(\mathrm{p}=0,000)$, dan penggunaan APD $(\mathrm{p}=0,480)$ dengan efek neurobehavioral pada petani cabai merah di Kecamatan Beringin.

\section{BIBLIOGRAFI}

Bouwknegt, M., Devleesschauwer, B., Graham, H., Robertson, L. J., \& Van Der Giessen, J. W. B. (2018). Prioritisation Of Food-Borne Parasites In Europe, 2016. Eurosurveillance, 23(9), 17-161.

Gusti, A., \& Desnizar, I. (2017). FaktorFaktor Yang Berhubungan Dengan Gejala Neurotoksik Akibat Paparan Pestisida Pada Petani Sayuran Di Kenagarian Alahan Panjang Kabupaten Solok. Jurnal Kesehatan Lingkungan Indonesia, 16(1), 17-21.

Kandel, E. R., \& Squire, L. R. (2000). Neuroscience: Breaking Down Scientific Barriers To The Study Of Brain And Mind. Science, 290(5494), 1113-1120.

Kim, S., Chen, J., Cheng, T., Gindulyte, A., He, J., He, S., Li, Q., Shoemaker, B. A., Thiessen, P. A., \& Yu, B. (2019). Pubchem 2019 Update: Improved Access To Chemical Data. Nucleic Acids Research, 47(D1), D1102-D1109.

Meryana, E., Budiono, A., \& Sutyanto, D. (2016). Palm Oil. Available From: Www. Indonesia-Investments. Com/Business/Commodities/PalmOil/Item166.

Organization, W. H. (2013). Global Tuberculosis Report 2013. World Health Organization.

Rahmadani, A. (2020). Analisis Kesesuaian Penggunaan Apd Menurut Permenakertrans No. 08 Tahun 2010 Pada Pekerja Di Workshop Pt. Surya Kabel Cemerlang Bogor Tahun 2010. Universitas Binawan. 
Hubungan Pajanan Pestisida dengan Efek Neurobehavioral pada Petani Cabai Merah di Kecamatan Beringin

Rahmah, N. N., Sakai, K., Sano, K., \& Hongo, K. (2012). Expression Of Reck In Endothelial Cells Of Glioma: Comparison With Cd34 And Vegf Expressions. Journal of NeuroOncology, 107(3), 559-564.

Samosir, K., Setiani, O., \& Nurjazuli, N. (2017). Hubungan Pajanan Pestisida Dengan Gangguan Keseimbangan Tubuh Petani Hortikultura Di Kecamatan Ngablak Kabupaten Magelang. Jurnal Kesehatan Lingkungan Indonesia, 16(2), 63-69.

Svennigsen, Å. F., \& Dahlin, L. B. (2013). Repair Of The Peripheral NerveRemyelination That Works. Brain Sciences, 3(3), 1182-1197.

Zhang, Y., \& Wallace, B. (2015). A Sensitivity Analysis Of (And Practitioners' Guide To) Convolutional Neural Networks For Sentence Classification. Arxiv Preprint Arxiv: 1510.03820. 